\title{
The Effect of Hydrocortisone on Immunoglobulin Metabolism
}

\author{
Arthur L. Levy and Thomas A. WaldmanN \\ From the Metabolism Branch, National Cancer Institute, National Institutes of \\ Health, Bethesda, Maryland 20014
}

A B STRACT The serum concentration of all subclasses of $\operatorname{IgG}\left(\gamma_{2} \mathrm{~A}, \boldsymbol{\gamma}_{2} \mathrm{~B}\right.$, and $\left.\boldsymbol{\gamma}_{1}\right)$ as well as $\operatorname{IgA}$ and IgM were reduced in normal and low pathogen mice receiving hydrocortisone acetate. Turnover studies using ${ }^{121} \mathrm{I}$-labeled $\boldsymbol{\gamma}_{2} \mathrm{~A}$ subclass of IgG demonstrated that high dose corticosteroids cause a significantly shortened survival (increased catabolic rate) which contributes to the observed hypogammaglobulinemia. This increase in fractional catabolism is not due to excess loss in the urine or stool but reflects an increase in endogenous catabolism.

\section{INTRODUCTION}

In recent years, $\mathrm{ACTH}$ and the adrenal steroids have come into widespread clinical use in the treatment of Addison's disease, the "autoimmune" diseases, ulcerative colitis, asthma, other allergies, and hematologic malignancies, and as an immunosuppressive in organ transplantation. Along with their beneficial effects, use of these hormones has produced undesirable side effects, including increased susceptibility to infection and inhibition of antibody synthesis (1-3).

Low serum gamma globulin concentrations have been observed in association with corticosteroid therapy (4). Several investigators have concluded that the low serum gamma globulin level is due to decreased synthesis alone (1-3). However, it is well known that steroid administration results in the hypercatabolism of many proteins (with resultant negative nitrogen balance) including albumin (5-7). Consequently, the possibility arises that at least part of the cause of the low serum gamma globulin concentration in the presence of corticosteroids is increased gamma globulin catabolism.

In the present study the effect of hydrocortisone on the rate of catabolism of IgG was determined by using metabolic turnover experiments. It was found that the hormone did enhance IgG catabolism. The lowered serum gamma globulin concentration must therefore result, at least in part, from this factor.

\footnotetext{
Received for publication 16 March 1970.
}

\section{METHODS}

Mice. Low pathogen BALB/c mice weighing 18-22 $\mathrm{g}$ were obtained from the National Institutes of Health's low pathogen colony, and conventional $\mathrm{BALB} / \mathrm{c}$ mice of the same size were obtained from the NIH general purpose colony.

${ }^{131}$ I-labeled protein. IgG protein for use in turnover experiments was isolated from the ascitic fluid (kindly supplied by Dr. Richard Asofsky) of LPC-1 tumor-bearing mice by Geon-Pevikon ${ }^{1}$ block electrophoresis. LPC-1 ascitic fluid contains an IgG myeloma protein of the $\gamma_{2} \mathrm{~A}$ subclass. This protein has been shown to be chemically and metabolically homogenous and has a relatively long half-life as compared to other mouse IgG subclasses. The $\gamma_{2} \mathrm{~A}$ preparation was tested by double diffusion in agar against specific and polyvalent sheep antisera to mouse immunoglobulins, and no contaminating protein was identified.

Experimental protocol. All mice were kept in cages with wood shavings. Low pathogen mice were kept in a clean hood and fed sterile food and water. All animals were given drinking water containing $0.45 \% \mathrm{NaCl}$ and $0.01 \% \mathrm{KI}$ to prevent thyroidal uptake of ${ }^{181} \mathrm{I}$ and to promote excretion of the free radioiodide released upon protein degradation.

The mice were divided into the following three groups: controls, low dose steroid, and high dose steroid. In all experiments, the control animals received daily subcutaneous injections of $0.1 \mathrm{ml}$ of sterile saline. As indicated below, the low dose group received $0.25 \mathrm{mg}$ of hydrocortisone acetate (Nutritional Biochemicals Corporation, Cleveland, Ohio) in $0.1 \mathrm{ml}$ of sterile saline, and the high dose group received 2.5 or $5 \mathrm{mg}$ of hydrocortisone acetate in $0.1 \mathrm{ml}$ of sterile saline. Between 25 and 50 mice were used in each experimental group.

IgG turnover studies were begun on the 8th day of steroid or saline injections. At that time, all mice were injected intravenously with approximately $1 \mu \mathrm{Ci}$ of ${ }^{181} \mathrm{I}$-labeled $\gamma_{2} \mathrm{~A}$. The whole body radioactivity was determined daily or every other day in a gamma ray small animal counter (BairdAtomic, Inc., Cambridge, Mass.) with an appropriate standard. The rate of decline of radioactivity in the serum was determined by sacrificing several animals from each group every day or every other day. After determining the hematocrit, the blood was placed in previously weighed vials and was counted in a Nuclear-Chicago auto-gamma counter with an appropriate standard.

\footnotetext{
${ }^{1}$ Geon Resin, The B. F. Goodrich Company, Niagara Falls, N. Y.; Pevikon C-870, Mercer Chemical Corp., New York.
} 
TABLE I

Effect of Hydrocortisone on the Immunoglobulin Subclass Levels in Normal Mice

\begin{tabular}{crrrrr}
\hline & IgM \pm SD & \multicolumn{1}{c}{ IgA } & \multicolumn{1}{c}{$\gamma_{1}$} & \multicolumn{1}{c}{$\gamma_{2} \mathrm{~A}$} & \multicolumn{1}{c}{$\gamma_{2} \mathrm{~B}$} \\
\hline Control & $m g / m l$ & & & & \\
(saline) & 0.473 & 0.640 & 1.593 & 1.693 & 0.510 \\
Low dose & \pm 0.107 & \pm 0.255 & \pm 0.377 & \pm 0.750 & \pm 0.075 \\
0.25 mg of hydrocortisone & 0.492 & 0.670 & 1.120 & 1.340 & 0.205 \\
High dose & \pm 0.092 & \pm 0.177 & \pm 0.402 & \pm 0.385 & \pm 0.080 \\
2.5 mg of hydrocortisone & 0.216 & 0.520 & 0.502 & 0.792 & 0.188 \\
& \pm 0.128 & \pm 0.247 & \pm 0.256 & \pm 0.420 & \pm 0.098 \\
\hline
\end{tabular}

Immunoglobulin levels ( $\operatorname{Ig} M, \operatorname{Ig} A, \gamma_{2} \mathrm{~A}, \gamma_{2} \mathrm{~B}, \gamma_{1}$ ) were determined by the radial diffusion technique of Fahey and McKelvey (8) with specific antisera provided by Dr. Richard Asofsky.

Methods of analysis of data. Plasma volumes were calculated using standard isotope dilution formulae, i.e., by determining the dilution of a known amount of intravenously administered protein- ${ }^{131} \mathrm{I}$ tracer after $10 \mathrm{~min}$ was allowed for mixing.

The per cent of radioactivity remaining in the whole body and in the serum was plotted on semilogarithmic paper. Whole body counts fell as a straight line function, and serum radioactivity fell as a straight line function after an initial rapid drop representing the distribution phase. The biologic half-life of the $\gamma_{2} \mathrm{~A}$ species was determined from the slope of the whole body curve and the terminal slope of the serum curve.

The fraction of the intravascular pool catabolized per day (FCR) was determined by the analysis of the serum curves into the sum of their exponential functions by the method of Matthews (9), using the formula

$$
F C R=\frac{1}{\frac{C_{1}}{B_{1}}+\frac{C_{2}}{B_{2}}+\frac{C_{n}}{B_{n}}}
$$

where $B_{1}=$ terminal slope of serum curve, $C_{1}=$ intercept of line extrapolated from terminal slope, and $B_{2}, C_{2}, B_{n}, C_{n}$, etc., are slopes and intercepts of exponential functions "peeled" from the serum curve.

Total circulating $\gamma_{2} \mathrm{~A}$ was calculated from the serum $\gamma_{2} \mathrm{~A}$ concentration $\left(\mathrm{S}_{\gamma_{2}} \mathrm{~A}\right)$ and the plasma volume (PV) using the formula: $T C \gamma_{2} A=\left(S \gamma_{2} A\right)(P V)$. Gamma globulin turnover was calculated from the formula $\gamma_{2} \mathrm{~A}$ turnover $=$ $\left(\mathrm{TC} \gamma_{2} \mathrm{~A}\right)(\mathrm{FCR})$.

In the steady state, $\gamma_{2} \mathrm{~A}$ turnover $=$ synthetic rate. However, in the steroid-treated animals, the synthetic rate thus obtained represented a theoretical maximum since serum $\gamma_{2} \mathrm{~A}$ levels were falling, and the weight of the animals was -declining.

\section{RESULTS}

Effect of steroids on immunoglobulin levels. As may be seen in Tables I and II, the immunoglobulin levels tended to be lower in the steroid-treated groups than in the control groups. The differences were significant (Student's $t$ test $P<0.05$ ) between the high dose and control groups (except for IgA in the normal pathogen group), but generally they were not significant between the low dose and control groups.

The immunoglobulin levels could theoretically have been lowered without lowering the total circulating IgG if the corticosteroids had increased the plasma volume. Plasma volume determinations, however, revealed no significant differences between groups (Table III). The differences in immunoglobulin concentration, therefore, were not dilutional.

Effect of steroids on catabolic rate in low pathogen mice. Animals receiving a high dose of hydrocortisone ( 2.5 or $5.0 \mathrm{mg} / \mathrm{mouse}$ ) had a significantly higher catabolic rate for the $\gamma_{2} \mathrm{~A}$ subclass of IgG than did controls,

TABLE II

Effect of Hydrocortisone on the Immunoglobulin Subclass Levels in Low Pathogen Mice

\begin{tabular}{crrrrr}
\hline & IgM \pm SD & \multicolumn{1}{c}{ IgA } & \multicolumn{1}{c}{$\gamma_{1}$} & \multicolumn{1}{c}{$\gamma_{2} \mathrm{~A}$} & \multicolumn{1}{c}{${ }_{2} \mathrm{~B}$} \\
\hline Control & $m g / m l$ & & & & \\
(saline) & 0.787 & 0.275 & 0.626 & 0.365 & 0.156 \\
Low dose & \pm 0.152 & \pm 0.104 & \pm 0.181 & \pm 0.216 & \pm 0.082 \\
0.25 mg of hydrocortisone & 0.888 & 0.295 & 0.605 & 0.236 & 0.118 \\
High dose & \pm 0.248 & \pm 0.026 & \pm 0.159 & \pm 0.104 & \pm 0.023 \\
2.5 mg of hydrocortisone & 0.164 & 0.177 & 0.106 & 0.140 & 0.050 \\
& \pm 0.121 & \pm 0.047 & \pm 0.042 & \pm 0.092 & \pm 0.008 \\
\hline
\end{tabular}


TABLE III

The Effect of Hydrocortisone on the Metabolism of Immunoglobulins

\begin{tabular}{|c|c|c|c|c|c|c|}
\hline & $\gamma_{2} \mathrm{~A}$ & PV & $\mathrm{TC}_{\gamma_{2} \mathrm{~A}}$ & $T_{1}$ & FCR & $\begin{array}{l}\text { Synthetic } \\
\text { rate }\end{array}$ \\
\hline & $m g / m l$ & $\mathrm{cc} / \mathrm{kg}$ & $m g / k g$ & days & $F x / d a y$ & $m g / k g / d a y$ \\
\hline \multicolumn{7}{|l|}{ Low pathogen group } \\
\hline Control (saline) & 0.365 & 24.0 & 8.8 & 6.9 & 0.197 & 1.73 \\
\hline Low dose ( $0.25 \mathrm{mg}$ of hydrocortisone) & 0.235 & 24.0 & 5.6 & 8.4 & 0.197 & 1.10 \\
\hline High dose (2.5 mg of hydrocortisone) & 0.140 & 24.0 & 3.4 & 4.0 & 0.340 & * \\
\hline \multicolumn{7}{|l|}{ Normal pathogen group } \\
\hline Control & 1.69 & 22.0 & 37.1 & 3.7 & 0.27 & 10.06 \\
\hline Low dose & 1.34 & 21.0 & 28.1 & 5.0 & 0.20 & 5.63 \\
\hline High dose & 0.79 & 22.0 & 17.4 & 2.7 & 0.52 & $*$ \\
\hline
\end{tabular}

* Synthetic rates for high dose animals could not be calculated because these animals were not in a steady state (see text).

whereas the catabolic rate in animals receiving a low dose of hydrocortisone ( $0.25 \mathrm{mg}$ per mouse) did not differ significantly from the catabolic rate in controls (Tables III and IV and Fig. $1 \mathrm{~A}$ and $\mathrm{B}$ ).

Low pathogen animals receiving the highest steroid dose $(2.5 \mathrm{mg})$ had a t of 4.0 days and an FCR of 0.340 /day as compared to a ti of 6.9 days and an FCR of $0.197 /$ day for control animals. Treatment of mice with $5.0 \mathrm{mg} /$ day did not further increase the fractional catabolic rate. Low pathogen animals which received an intermediate dose ( $1.0 \mathrm{mg}$ hydrocortisone acetate daily) had a t of 5.2 days as compared with 8.0 for controls.

Animals receiving a low dose of corticosteroid ( 0.25 $\mathrm{mg}$ of hydrocortisone acetate per day) had a whole body ti of 8.4 days, which was, if anything, slightly longer than the control t $t$ of 6.9 days. Serum curves, however, failed to reveal a significant difference in the fractional catabolic rate between low dose and control groups.

Effect of steroids on the catabolic rate in normal pathogen mice. The metabolism of $\gamma_{2} \mathrm{~A}$ subclass of $\mathrm{IgG}$ was studied in an identical manner in normal pathogen mice, who differ from those raised in a low pathogen environment in that their serum gamma globulin levels are higher. As in the low pathogen group, the half-life of IgG in normal pathogen mice treated with high doses of hydrocortisone was significantly shorter than that in controls, while there was no significant difference in t 3 between low dose and control groups (Table III). The half-life of IgG in all three groups of normal pathogen mice was significantly shorter than the half-life of IgG in the corresponding low pathogen groups. This can be explained by the concentration-catabolism effect, which will be discussed below.

Effect of steroids on IgG $\gamma_{s} A$ synthesis. The synthetic rate of the $\gamma_{2} \mathrm{~A}$ subclass of IgG was $1.73 \mathrm{mg} / \mathrm{kg}$ per day in control low pathogen animals (Table III) and $1.10 \mathrm{mg} / \mathrm{kg}$ per day in animals receiving $0.25 \mathrm{mg}$ of hydrocortisone acetate daily. For the normal pathogen group, the values were $10.06 \mathrm{mg} / \mathrm{kg}$ per day for controls and $5.63 \mathrm{mg} / \mathrm{kg}$ per day for low dose steroid-treated groups. These differences were not statistically significant $(0.3>P>0.2)$. The synthetic rates for the high dose steroid-treated groups could not be determined since the animals were not in a steady state. Rather, their body weights and serum immunoglobulin concentrations were rapidly falling.

From this data, therefore, we cannot say with certainty that corticosteroids cause decreased synthesis of immunoglobulins.

Effect of steroids on proteinuria, gastrointestinal blood loss, and free iodide clearance. The following studies were designed to investigate the possibility that

TABLE IV

The Effect of Augmentation of Gamma Globulin Levels on the Catabolism of IgG in Low Pathogen Mice Corticosteroid-Induced Hypercatabolism?

\begin{tabular}{ccccccc}
\hline & $\begin{array}{c}\text { Control } \\
\text { (saline) }\end{array}$ & $\begin{array}{c}\text { Control } \\
\text { +gamma } \\
\text { globulin }\end{array}$ & $\begin{array}{c}\text { Intermediate dose } \\
(1.0 \text { mg of hydro } \\
\text { cortisone })\end{array}$ & $\begin{array}{c}\text { Intermediate dose } \\
\text { +gamma globulin }\end{array}$ & $\begin{array}{c}\text { High dose } \\
\text { (2.5 mg of } \\
\text { hydrocortisone) }\end{array}$ & $\begin{array}{c}\text { High dose } \\
\text { +gamma } \\
\text { globulin }\end{array}$ \\
\hline $\begin{array}{c}\mathrm{t}_{3} \\
\text { (days) }\end{array}$ & 8.0 & 1.5 & 5.2 & 1.75 & 4.0 & 1.3 \\
\hline
\end{tabular}



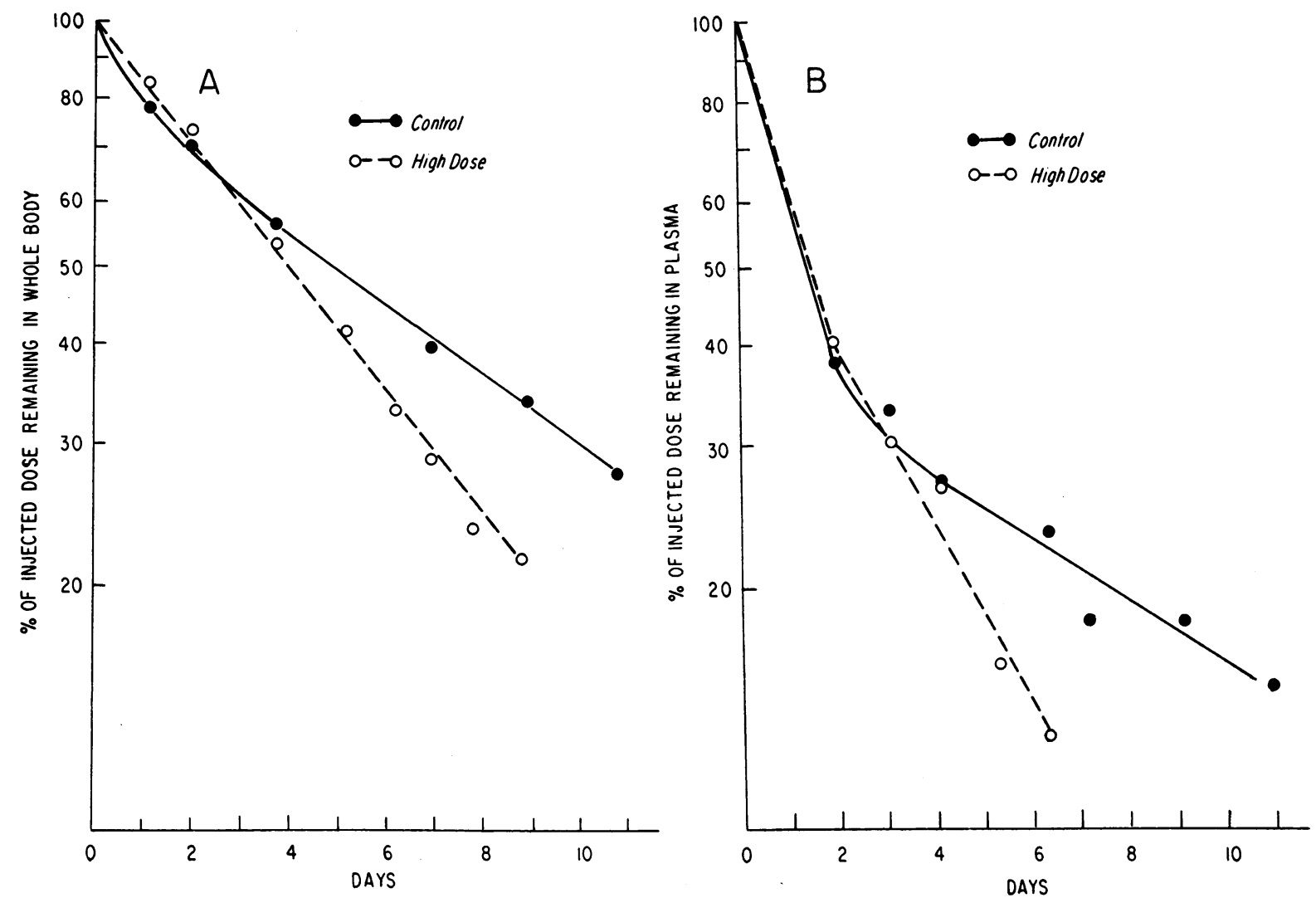

FIGURE 1 (A) Effect of high dose corticosteroids on the whole body survival $\left(t_{\frac{1}{3}}\right)$ of $\gamma_{2} A-{ }^{181} I$ in low-pathogen mice. (B) Effect of high dose corticosteroids on the rate of disappearance of $\gamma_{2} \mathrm{~A}-181$ from the serum (FCR) of low-pathogen mice.

the increased rate of disappearance of IgG could be due to proteinuria, gastrointestinal blood loss, or altered free iodide clearance.

(a) IgG was labeled with ${ }^{181} \mathrm{I}$ as described above and was administered intravenously to control and high dose steroid-treated mice. All urine was collected for 4 days and protein-bound radioactivity was determined for each animal by precipitating urinary protein with $10 \%$ trichloroacetic acid. There was no significant increase in protein-bound radioactivity in the urine of steroidtreated animals as compared with controls, thus ruling out proteinuria as the cause of the high catabolic rate.

(b) Mice whose red blood cells were labeled in vivo by citrate ${ }^{-59} \mathrm{Fe}$ were divided into high dose steroidtreated and control groups. At the 7th day after the start of daily corticosteroid administration, and the 8th day after ${ }^{50} \mathrm{Fe}$ administration, each animal was placed in a metabolic cage, and stool was collected for 4 days. There was no significant difference in stool counts between steroid-treated and control groups, and therefore the short IgG survival was not due to significant loss of whole blood into the gastrointestinal tract. (c) The shortened IgG survival was also not due to altered free-iodide clearance. $\mathrm{Na}^{218 \mathrm{I}} \mathrm{I}$ was administered intravenously to control and high dose steroid-treated mice. Subsequent turnover studies demonstrated no difference between control and steroid-treated animals in the rate of free-iodide clearance.

Thus, the increased fractional catabolic rate in animals on high dose steroids was not due to loss in the urine or stool or altered excretion of free iodide but reflected an increase in endogenous catabolism.

Effect of steroids on the concentration-catabolism effect. IgG metabolism is characterized by a concentration-catabolism effect in which the FCR varies directly with the serum IgG concentration (10). That is, as the concentration of IgG rises the fractional rate of catabolism increases (the tocreases) until a limiting concentration is reached. The following experiment was designed to study whether steroids could be effecting the increased fractional catabolism of IgG by abolition or marked alteration of the concentration-catabolism effect. 
Turnover studies with $\gamma_{2} \mathrm{~A}-{ }^{181} \mathrm{I}$ were performed on groups of low pathogen mice receiving saline, $1.0 \mathrm{mg}$ of hydrocortisone acetate, or $2.5 \mathrm{mg}$ of hydrocortisone acetate daily. On the 4th day of the study each of these groups was divided into two subgroups. In each case one subgroup continued on the turnover study as before, thereby acting as a control group for the other subgroup which received $50 \mathrm{mg}$ of rabbit gamma globulin (Mann Research Labs. Inc., New York) intraperitoneally on day 4 followed by daily intraperitoneal injections of $10 \mathrm{mg}$ of Rabbit gamma globulin. The results were as follows (Table IV and Fig. 2). The saline group with augmented gamma globulin levels had a survival half-time ( $\left.t_{t}\right)$ of 1.5 days as compared with 8.0 days for its control group. The intermediate dose group (1.0 $\mathrm{mg}$ of hydrocortisone acetate) with augmented gamma globulin levels had a $t$ of 1.75 days, compared with 5.2 days for its control. The high dose group ( $2.5 \mathrm{mg}$ of hydrocortisone acetate) with augmented gamma globulin levels had a $t$ of 1.3 days, compared with 4.0 days for its control.

Thus, the increased fractional catabolism of IgG caused by high doses of corticosteroids is not due to abolition or marked alteration of the concentrationcatabolism phenomenon.

\section{DISCUSSION}

In the present study, the mice receiving high doses of hydrocortisone acetate had a significantly reduced concentration of all subclasses of $\operatorname{IgG}, \operatorname{IgA}$, and $\operatorname{IgM}$ ( Tables I and II). These results confirm and extend previous observations which indicated that adrenocortical steroid administration results in reduced IgG levels.

Most investigators who have studied this phenomenon have concluded that the decreased serum immunoglobulin levels of animals on steroids can be attributed to the decreased synthetic rate alone (1-3).

Our data neither confirm nor refute the contribution of decreased synthetic rate, but they do demonstrate that adrenocortical steroids in high doses markedly increase the fractional catabolic rate of the immunoglobulins.

The difference between our findings and the findings of those who did not find increased catabolism of immunoglobulin in the presence of steroids may be explained by several factors. First of all, we used a much higher steroid dose. Whereas Germuth, Oyama, and Ottinger (3) used doses of 4 and $5 \mathrm{mg}$ of compound $\mathrm{E}$ (17-hydroxy-11-dehydroxycorticosterone) and Fischel, Stoerk, and Bjфrneboe (2) used $10 \mathrm{mg}$ of cortisone per adult rabbit per day, we used $5,2.5$, and $1 \mathrm{mg}$ of hydrocortisone per mouse, a much higher dose on a weight basis. Secondly, they either used measurements of antibody nitrogen or the Arthus reaction to follow the im-

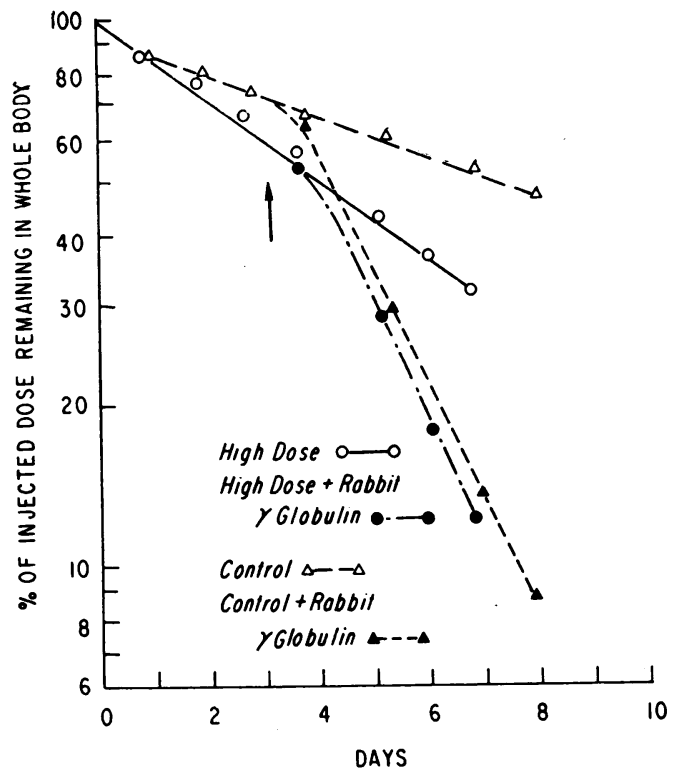

FIGURE 2 The effect of altered gamma globulin levels on the IgG survival of control and steroid-treated low-pathogen mice. The arrow denotes the time at which augmentation of gamma globulin levels (by intraperitoneal infusion of rabbit gamma globulin) was begun in half of the mice in each group (controls and high dose corticosteroid).

munoglobulin metabolism, relatively insensitive methods compared to turnover studies with ${ }^{131}$ I-labeled immunoglobulin.

It is noteworthy that Andersen (11) observed that treatment with prednisone seemed to increase the fractional catabolic rate in patients with cirrhosis of the liver and hypergammaglobulinemia. Andersen did not observe a similar phenomenon in patients with rheumatoid arthritis and hypergammaglobulinemia who were, however, receiving smaller doses of prednisone.

Shortened survival of a serum protein may theoretically be due to loss of protein in the urine (i.e., nephrosis) or in the gastrointestinal tract (i.e., protein-losing enteropathies) or may be due to increased endogenous catabolism. As may be seen above, we have ruled out bulk loss of serum protein through proteinuria or gastrointestinal bleeding. We also ruled out a corticosteroidinduced alteration in clearance of the free radioiodide by the kidney. Therefore, the increased FCR appears to be due to an increase in endogenous catabolism.

The catabolism of immunoglobulins is determined in part by factors that affect all serum proteins and in part by specific factors. One of the latter is the concentration-catabolism effect of IgG already alluded to above. This phenomenon is seen in many species, including mice, but is not seen in all species (12). If steroids were to abolish this phenomenon in some manner, a short IgG survival could result. 
We found, however, that the concentration-catabolism effect remained operative on the basis of the experiment outlined in results, and the fact that normal pathogen animals, who had a higher gamma globulin level than the low pathogen mice, had a correspondingly increased FCR in both control and steroid-treated groups. This, of course, does not exclude the possibility of more subtle corticosteroid-induced changes in the mechanism responsible for the concentration-catabolism effect.

The metabolic rate is one of the general factors which appear to influence the catabolism of many proteins, including the gamma globulins. This presumably accounts for the difference in catabolic rates among different species. Thus, Dixon, Talmage, Maurer, and Deichmiller (13) showed that gamma globulin half-life varied directly with the size of the species and inversely with its metabolic rate. Also, Farthing, Gerwing, and Shewell (14) showed an increased gamma globulin survival in hypothyroid rats and a decreased IgG survival in hyperthyroid animals.

The adrenal steroids seem to exert a similar general metabolic effect on a variety of proteins. Numerous investigators have demonstrated negative nitrogen balance in the presence of steroids (5). Flick and Steinfeld demonstrated hypercatabolism of albumin in man under the influence of fever and ACTH, and Rothschild, Schreiber, Oratz, and McGee (7) demonstrated increased catabolism of ${ }^{281} \mathrm{I}$-labeled albumin in patients receiving adrenocortical hormones.

The mechanisms for the effect of corticosteroids on serum protein catabolism noted above are not well understood. It has been shown, however, that certain hormones, including the glucocorticoids, induce the synthesis of certain enzyme systems involved with the metabolism of amino acids (15-17). The effect of the adrenal steroids on the catabolism of IgG could reflect a similar induction of enzymes responsible for IgG catabolism or the transport of IgG to catabolic sites. Further work is necessary to explore these possibilities.

\section{ACKNOWLEDGMENT}

The technical assistance of Mrs. Jeanne Harnsberger was invaluable.

\section{REFERENCES}

1. Bjфrneboe, M., E. E. Fischel, and H. C. Stoerk. 1951. The effect of cortisone and adrenocorticotrophic hormone on the concentration of circulating antibody. J. Exp. Med. 93: 37 .
2. Fischel, E. E., H. C. Stoerk, and M. Bjфrneboe. 1951. Failure of cortisone to affect rate of disappearance of antibody protein. Proc. Soc. Exp. Biol. Med. 77: 111.

3. Germuth, F. G., J. Oyama, and B. Ottinger. 1951. The mechanism of action of 17-hydroxy-11-dehydrocorticosterone (compound $\mathrm{E}$ ) and of the adrenocorticotropic hormone in experimental hypersensitivity in rabbits. J. Exp. Med. 94: 139.

4. Jager, B. V., H. Brown, and M. Nickerson. 1951. Alterations in plasma proteins, plasma volume, and volume of packed red cells in patients receiving ACTH or cortisone. J. Lab. Clin. Med. 37: 431.

5. Bergenstal, D. M., R. L. Landau, J. Kirsner, and K. Lugibihl. 1951. Effects of ACTH and related hormones on amino acid metabolism. In Proceedings of the Second Clinical ACTH Conference. J. Mote, editor. Blakiston Division of the McGraw-Hill Book Co., Inc., New York. $1: 250$.

6. Flick, A. L., and J. L. Steinfeld. 1958. Effect of fever and corticotropin on the in vivo degradation of albumin in man as measured with iodinated human serum albumin. Amer. J. Med. Sci. 236: 65.

7. Rothschild, M. A., S. S. Schreiber, M. Oratz, and H. L. McGee. 1958. The effects of adrenocortical hormones on albumin metabolism studied with albumin- $\mathrm{I}^{131} . J$. Clin. Invest. 37 : 1229.

8. Fahey, J. L., and E. M. McKelvey. 1965. Quantitative determination of serum immunoglobulins in antibody-agar plates. J. Immunol. 94: 84.

9. Matthews, C. M. E. 1957. The theory of tracer experiments with ${ }^{131}$ I-labelled plasma proteins. Phys. Med. Biol. 2: 36 .

10. Fahey, J. L., and S. Sell. 1965. The immunoglobulins of mice. V. The metabolic (catabolic) properties of five immunoglobulin classes. J. Exp. Med. 122: 41.

11. Andersen, S. B. 1964. Metabolism of Human Gamma Globulin ( $\gamma_{s s}-$ globulin). F. A. Davis Co., Philadelphia, $\mathrm{Pa} .58$.

12. Sell, S. 1964. Evidence for species' differences in the effect of serum $\gamma$-globulin concentration on $\gamma$-globulin catabolism. J. Exp. Med. 120: 967.

13. Dixon, F. J., D. W. Talmage, P. H. Maurer, and M. Deichmiller. 1952. The half-life of homologous gamma globulin (antibody) in several species. J. Exp. Med. 96: 313.

14. Farthing, C. P., J. Gerwing, and J. Shewell. 1960. The catabolism of ${ }^{131}$ I-labelled homologous $\gamma$-globulin in normal, hyperthyroid and hypothyroid rats. J. Endocrinol. 21: 83 .

15. Watanabe, M., V. R. Potter, and H. C. Pitot. 1968. Systematic oscillation in tyrosine transaminase and other metabolic functions in liver of normal and adrenalectomized rats on controlled feeding schedules. J. Nutr. 95: 207.

16. Peraino, C. 1968. Regulatory effects of glucocorticoids on ornithine amino-transferase and serine dehydratase in rat liver. Biochim. Biophys. Acta. 165: 108

17. Schimke, R. T. 1967. Protein turnover and the regulation of enzyme levels in rat liver. Nat. Cancer Inst. Monogr. No. 27. 301. 